\title{
Experimental Study of the Effect of Increased Compression Ratio on the Torque and Power of the Honda CB 150R Engine Using E85 Fuel
}

\section{Studi Eksperimen Pengaruh Peningkatan Rasio Kompresi Terhadap Torsi dan Daya Engine Honda CB 150R Berbahan Bakar E85}

Yuli Mafendro D. E. S ${ }^{*}$, Muhammad Hidayat Tullah ${ }^{1}$

\begin{abstract}
Switching from fossil fuels to alternative fuels requires adjusting several engine parameters to avoid a decrease in engine torque and power. This happens because of the different properties of different fuels. One of the parameters that must be set is the compression ratio. This study aims to determine the effect of increasing the compression ratio on the torque and power of the Honda CB 150R engine using 85\% bioethanol (E85) as fuel. The research method used an experimental method with 2 types of fuel and variations in the compression ratio. From the research results, it can be seen that the torque and power using E85 fuel have increased respectively by $1.08 \%$ and $1.5 \%$ when compared to the standard compression ratio using fossil fuels.
\end{abstract}

Keywords

Ratio compression, bioethanol 85\%, Honda CB 150 R

\begin{abstract}
Abstrak
Pergantian bahan bakar dari fosil ke bahan bakar alternatif membutuhkan pengaturan pada beberapa parameter engine untuk menghindari terjadinya penurunan pada torsi dan daya mesin. Hal ini terjadi karena perbedaan dari properties bahan bakar yang berbeda. Salah satu parameter yang harus di atur adalah rasio kompresi. Penelitian ini bertujuan untuk mengatahui pengaruh dari peningkatan rasio kompresi terhadap torsi dan daya engine Honda CB 150R menggunakan bahan bakar bioetanol 85\% (E85). Metode penelitian menggunakan metode eksperimen dengan 2 jenis bahan bakar dan variasi pada rasio kompresi. Dari hasil penelitian terlihat bahwa torsi dan daya dengan menggunakan bahan bakar E85 mengalami peningkatan masing-masing sebesar 1,08 \% dan 1,5\% jika dibandingkan dengan rasio kompresi standard menggunakan bahan bakar fosil.
\end{abstract}

\section{Kata Kunci}

Rasio Kompresi, Bioetanol 85\%, Honda Cb 150 R

${ }^{1}$ Jurusan Teknik Mesin, Politeknik Negeri Jakarta.

Jl. Prof. G. A. Siwabessy, Kampus UI, Depok, 16425

*yulimafendro@mesin.pnj.ac.id

Submitted : January 04, 2021. Accepted : January 18, 2021. Published : January 31, 2021. 


\section{INTRODUCTION}

Gasoline is still the main fuel for Otto motor because of its properties which are very compatible with the combustion characteristics of the Otto motor. Gasoline which is a fossil fuel is a complex mixture consisting of hundreds of hydrocarbons which can be grouped into parafanic, naphanic and aromatic, has a boiling point between $30-220{ }^{\circ} \mathrm{C}$ with a carbon content of $\mathrm{C}_{4}-\mathrm{C}_{12}$ and a little sulfur, oxygen and nitrogen compounds. . The chemical composition of gasoline is highly dependent on crude oil raw materials (API, chemical composition), refinery processes (distilation, alkylation, hydrocracking, catalytic cracking), specifications and properties adapted to climatic conditions, requirements and specifications requested by Otto motor makers. (according to the applied technology) and pollutant threshold requirements [1].

Ethanol is an ethyl alcohol compound with the chemical formula $\mathrm{C}_{2} \mathrm{H}_{5} \mathrm{OH}$. Ethanol is obtained from the fermentation and distillation processes of food containing carbohydrates such as; corn, sugar cane, wheat, etc. The characteristics and physical properties of ethanol are colorless, volatile and flammable, therefore ethahanol is widely used in the manufacture of pharmaceuticals, liquor mixtures and vehicle fuels. Ethanol is one of the various types of fuel that has the most potential to be developed for alternative fuel for vehicles, especially in gasoline engines because ethanol has almost the same physical properties and combustion characteristics as gasoline.

The use of ethanol as a fuel in gasoline motorbikes (Otto) has been known since Henry Ford created the vehicle in 1896.After the exploration and exploitation of petroleum began to be carried out by humans, oil became the main and preferred type of fuel in gasoline motorized vehicles (Otto). Although fuel oil dominates the use of gasoline motorbikes, ethanol becomes an alternative again for the following reasons: (1) oxygenated "octan booster" as a substitute for Tertiary Methyl Butyl Ether (MTBE)-which is allegedly having a negative impact on the environment, (2) reducing emissions exhaust gas, and (3) reduce fuel oil consumption [1].

The use of ethanol as a mixture of gasoline with low levels, namely $10 \%$ ethanol and $90 \%$ gasoline (E10 or often called gasohol) for fuel on gasoline motorbikes has been carried out by countries such as Brazil, USA, and several other European countries. The use of E10 on a gasoline motorbike does not need changes or modifications to the motorbike because it is still compatible with premium fuel / gasoline. Meanwhile, the use of pure ethanol (dedicated fuel) or mixing ethanol with gasoline in a large percentage requires certain modifications because of the significant differences in physical and chemical characteristics / properties between ethanol and gasoline. Some of the changes that can be made are the compression ratio.

In this study, an increase in the compression ratio from the standard 11: 1 to 12: 1 using E85 fuel). And here are the properties of gasoline, ethanol, and gasoline ethanol mixture E85 which are presented in table 1.

Table 1. comparison of the properties of fossil fuels, ethanol, and E85

\begin{tabular}{cccc}
\hline Type of testing & Unit & Gasoline & E85 \\
\hline Spesifik grafity & - & 0.7391 & 0.7855 \\
\hline calorific value & $\mathrm{Kkal} / \mathrm{kg}$ & 10674.6 & 4640 \\
\hline $\mathrm{RON}$ & - & $91-98$ & $>111$ \\
\hline $\mathrm{RVP}$ & $\mathrm{KPA}$ & 5.59 & 5.46 \\
\hline Density & $\mathrm{Kg} / \mathrm{m}^{3}$ & 598,7 & 648,6 \\
\hline Lower Heating Value & $\mathrm{KJ} / \mathrm{Kg}$ & 42,9 & 29,2 \\
\hline
\end{tabular}


Compression ratio is one of the important variables in determining the performance of an otto engine. A high compression ratio will cause the density of the mixture and the turbulence of the mixture in the combustion chamber to increase so that it will increase the cylinder pressure followed by an increase in cylinder temperature and accelerate the combustion rate.

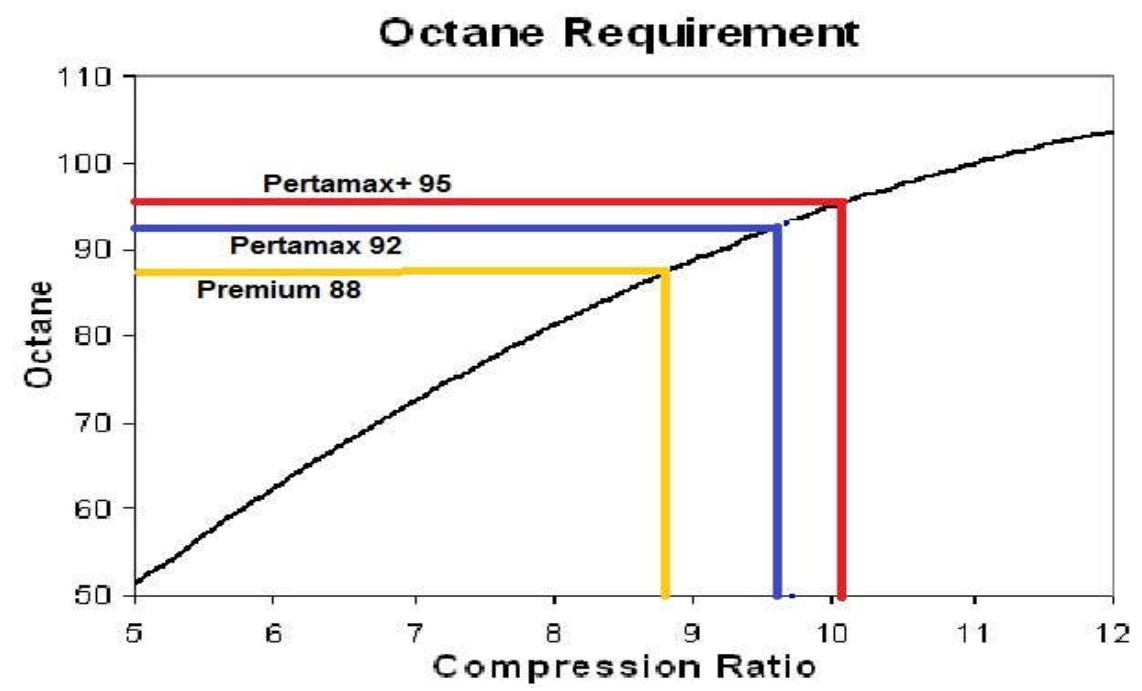

Figure 1 The relationship between the octane number and the compression ratio [2]

Figure 1 shows the relationship between the octane number and the compression ratio. The application of the otto engine compression ratio depends on the octane number of the fuel and the engine construction. which is when the octane number increases, the compression ratio also increases [2]. The otto engine uses gasoline with an octane number of 88-100 and is designed with a compression ratio of 9-10. The low octane number of gasoline can be increased by adding additive compounds as an octane booster, including tetra ethyl lead (TEL), methyl tertbutyl ether (MTBE). The existence of these additive compounds has an impact on increasing pollution and exhaust emissions. Therefore, the addition of ethanol in a low percentage in addition to increasing the octane number of gasoline can also reduce exhaust gas emissions [3]. The mixture of ethanol and gasoline has a fairly large octane range up to a concentration of $20 \%$ and is conical to 109 if pure ethanol is used as fuel. [4].

One of the combustion chamber geometries that is most taken into account in designing a combustion motor is the compression ratio shown in the following figure and equation.

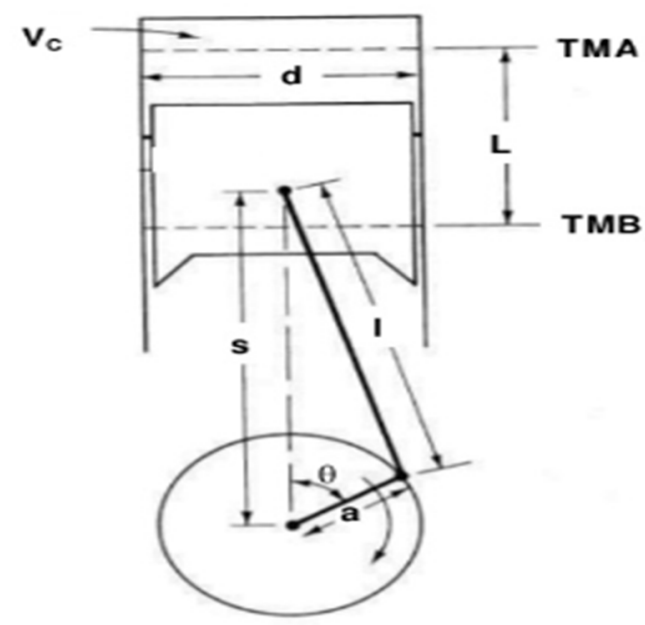

Figure 2. Combustion chamber geometry 


$$
r c=\frac{V c+V d}{V c}
$$

Where $:$ Vc $=$ Residual volume $\left(\mathrm{m}^{3}\right)$

$$
\mathrm{Vd}=\text { Displacement volume }\left(\mathrm{m}^{3}\right)
$$

The residual volume consists of the head gasket space, deck space and combustion chamber, therefore it changes the compression ratio by adding and subtracting the three sections. The exhaust volume on the piston ssat at TDC is $(s=\alpha+r)$, so that the connecting rod length and crank radius at each change in crank angle can be calculated by the equation:

$$
S(\theta)=a \cos \theta+\left(r^{2}-a^{2} \theta\right)^{1 / 2}
$$

And the cylinder volume at each change is the same:

$$
\mathbf{V}(\boldsymbol{\theta})=\mathrm{V}_{\mathrm{c}}+\frac{\pi B^{2}}{4}[\mathrm{r}+\mathrm{a}-\mathbf{s}(\boldsymbol{\theta})
$$

So that the maximum displacement volume is:

$$
V_{d}=\frac{\pi B 2}{4} L
$$

There are several ways that can be done to obtain the compression ratio practically, namely by changing the geometry of the piston by adding a bulge (dome) above it, taping the cylinder head so that it is closer to the piston using a thinner gasket. In this study, this method is used to increase the compression ratio.

Bahattin [5] conducted research on a single cylinder carburetor engine with stoichiometric conditions, at various compression ratios of 6: 1 and 10: 1 . Where the results of the research prove that increasing the compression ratio can increase engine performance by $25 \%$ as shown in the figure below.

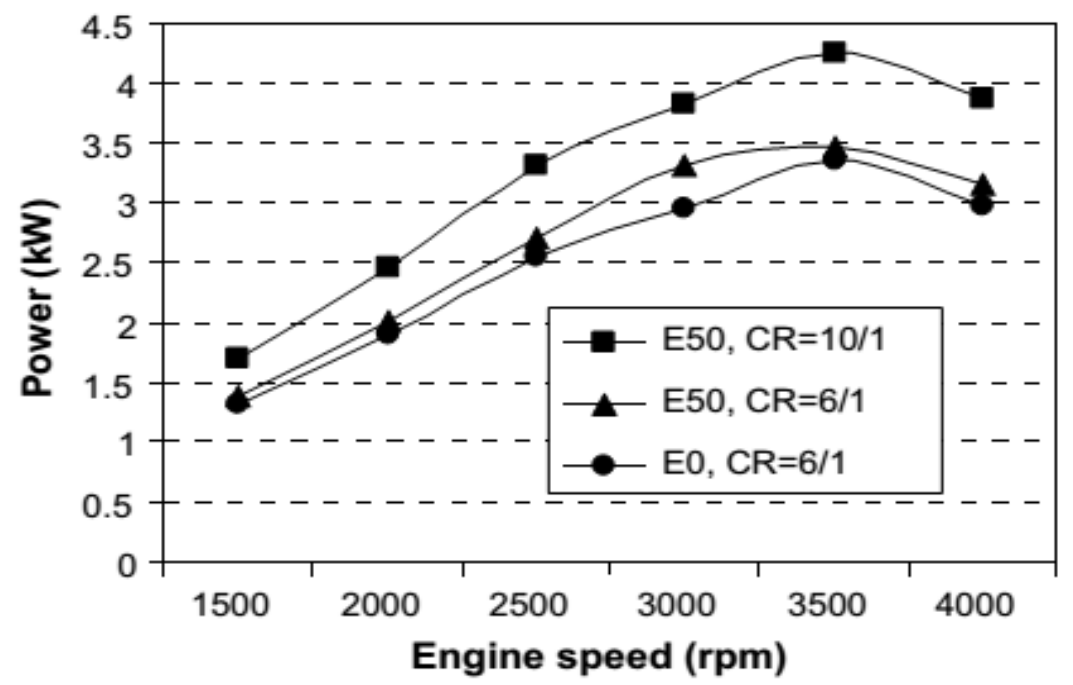

Figure 3 Effect of CR on Power on variations in concentration and rpm [5]

Rodrigo [6] also conducted a study by increasing the compression ratio from 11: 1 to 12: 1 using E22 where the results showed an increase in engine power by 3.1\%. Sudarmanta [7] conducted a study by increasing the compression ratio from 9.6: 1 to 11.6: 1 using E50 where the results of the research are as shown in the figure below: 


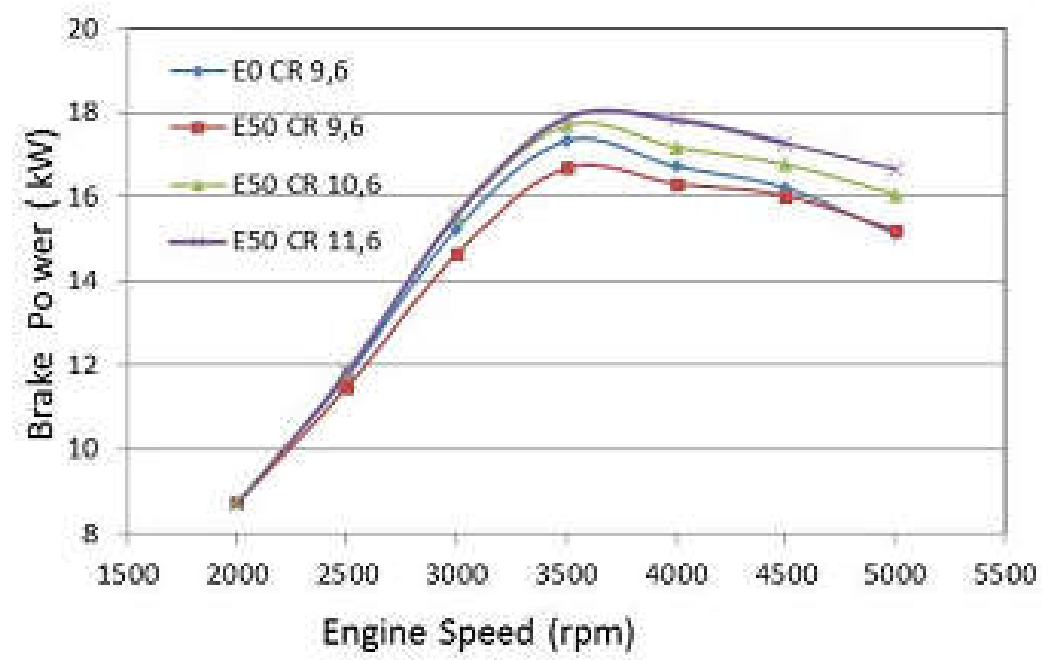

Figure 4. Brake power at variation compression ratio and engine speed. [7]

Figure 4 showed The increase of compression ratio will increases the power generated by the engine. The highest brake power output of $17,88 \mathrm{~kW}$ occurs at high speeds especially at $3500 \mathrm{rpm}$ and produced by compression ratio 11, 6 .

Ethanol has a reid vaporization pressure (RVP) value of $17 \mathrm{kPa}$. This value is much lower than gasoline which has an RVP value of $53.7 \mathrm{kPa}$ at a temperature of $37^{\circ} \mathrm{C}$. This condition requires a higher temperature to increase the vapor pressure of ethanol so that it can be atomized properly. Low ethanol vapor pressure makes the engine difficult to start in cold conditions, where the maximum vapor pressure is obtained if the percentage of ethanol in gasoline is $50-10 \%$. [8]. The solution to overcoming the difficult engine to live in cold conditions on ethanol fuel is to increase the temperature of the fuel before injecting it into the cylinder with a pre-heating device and also by using two fuel tanks. But the solution most often used is to use E85 (85\% ethanol plus 15\% gasoline). The addition of 15\% gasoline induces a strong increase in volatility and consequently starts the engine easier [9].

Tabel 2. Specifications Honda CB150R

\begin{tabular}{|c|c|}
\hline Keterangan & Specification \\
\hline Engine & Honda CB150R \\
\hline Type & 4 - single cylinder stroke (40o inclination from vertical) \\
\hline Valve system & $\mathrm{DOHC}$ \\
\hline Diameter bore & $63,5 \mathrm{~mm}$ \\
\hline Stride length & $47,2 \mathrm{~mm}$ \\
\hline Compretioon Rasio & $11,0: 1$ \\
\hline Valve opening & $5^{\circ}$ BTDC (at $1.00 \mathrm{~mm}$ lift) \\
\hline Valve closes & $35^{\circ}$ ATDC (at $1.00 \mathrm{~mm}$ lift) \\
\hline Exhaust valve opens & $35^{\circ} \mathrm{ABDC}$ (at $1.00 \mathrm{~mm}$ lift) \\
\hline Exhaust valve closes & $5^{\circ}$ BTDC (at $1.00 \mathrm{~mm}$ lift) \\
\hline Maximum power & 12.5 KW (17.0 PS) / $10000 \mathrm{rpm}$ \\
\hline Maximum torque & $13.1 \mathrm{Nm}(1.34$ Kgf.m) / $7000 \mathrm{rpm}$ \\
\hline
\end{tabular}




\section{RESEARCH METHODS}

This research was conducted using an experimental method on the Honda CB150R engine. There are two types of fuel to be used in this test. For reference data collection, the fuel used is Pertamax, while for data collection, the fuel used is E85 ethanol (85\% ethanol + 15\% Pertamax). The increase in compression ratio is from the standard 11: 1 to $12: 1$ at engine speed which varies between $2000 \mathrm{rpm}$ with an increase of every $1000 \mathrm{rpm}$ to 8000 rpm. To get good research results, this research is divided into several stages, namely : (1) Literature study regarding the use of high concentrations of bioethanol fuel in everyday motorcycle engines. (2) Tune Up of the Honda CB150R engine. (3) Testing the Honda CB150R engine with the Waterbrake Dynamometer test kit with Pertamax fuel $(0 \%$ ethanol). (4) Testing the Honda CB150R engine with the E85 Waterbrake Dynamometer test tool at a standard compression ratio (11: 1). (5) Testing the Honda CB150R engine with the E85 Waterbrake Dynamometer test tool at a compression ratio (12: 1).

\section{RESULTS AND DISCUSSION}

The following is the test data generated from the experimental results.

\section{Torque}

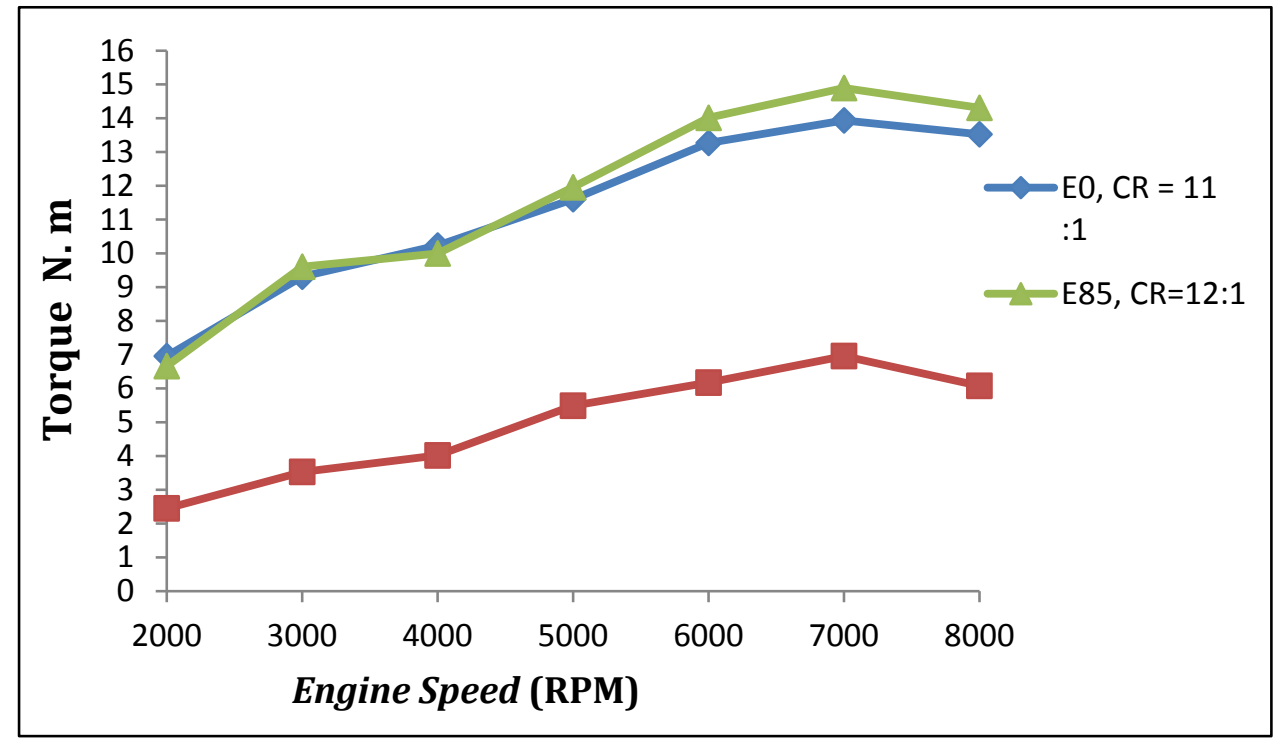

Figure 5. Torque of experimental

From Figure 5, it can be seen that there is a trend of increasing torque from low speed to maximum torque at a certain rotation. then the torque decreases at higher speed. This is because the higher the engine speed, the higher the turbulence of the flow that enters the combustion chamber and causes the mixing of fuel and air to get better and the flame propagation is also faster so that the torque will increase. After the higher engine speed, the greater the losses that occur, such as losses in the form of friction and incomplete combustion. the higher the engine speed, the greater the friction that occurs. In addition, combustion of the mixture of fuel and air in the combustion chamber also takes time. When the rotation is high, it is possible that the ignition that occurs is not fast enough to burn all the fuel in the combustion chamber, or in other words the more unburned fuel remains in the combustion chamber.

From the picture above, it can be seen that there is a very significant decrease in torque at every engine speed by changing the fuel from gasoline (Pertamax) to E85. If the sample is taken at the best torque, namely at 7000 RPM engine speed, the torque has decreased by $49 \%$. 
This is due to the different properties of the two types of fuel. The most significant property is the octane number of the fuel. It is well known that a higher octane number requires a higher compression ratio. This causes the use of E85 fuel at a compression ratio of 11: 1 to be ineffective, therefore an increase in the compression ratio is needed to reduce the decrease in torque. After increasing the compression ratio to 12: 1 using E85 fuel, there is an increase in torque at each engine speed. If you look at the best torque at a 7000 RPM engine torque, the torque has an increase of 4,6\% when compared to the $\mathrm{E} 85$ at a compression ratio of $11: 1$ and by $1.08 \%$ when compared to pure gasoline at a compression ratio of $11: 1$. This is because the higher octane number on the E85 requires a higher compression ratio so as to increase torque. The increased torque is due to a more complete combustion at 12: 1 torque

\section{Power}

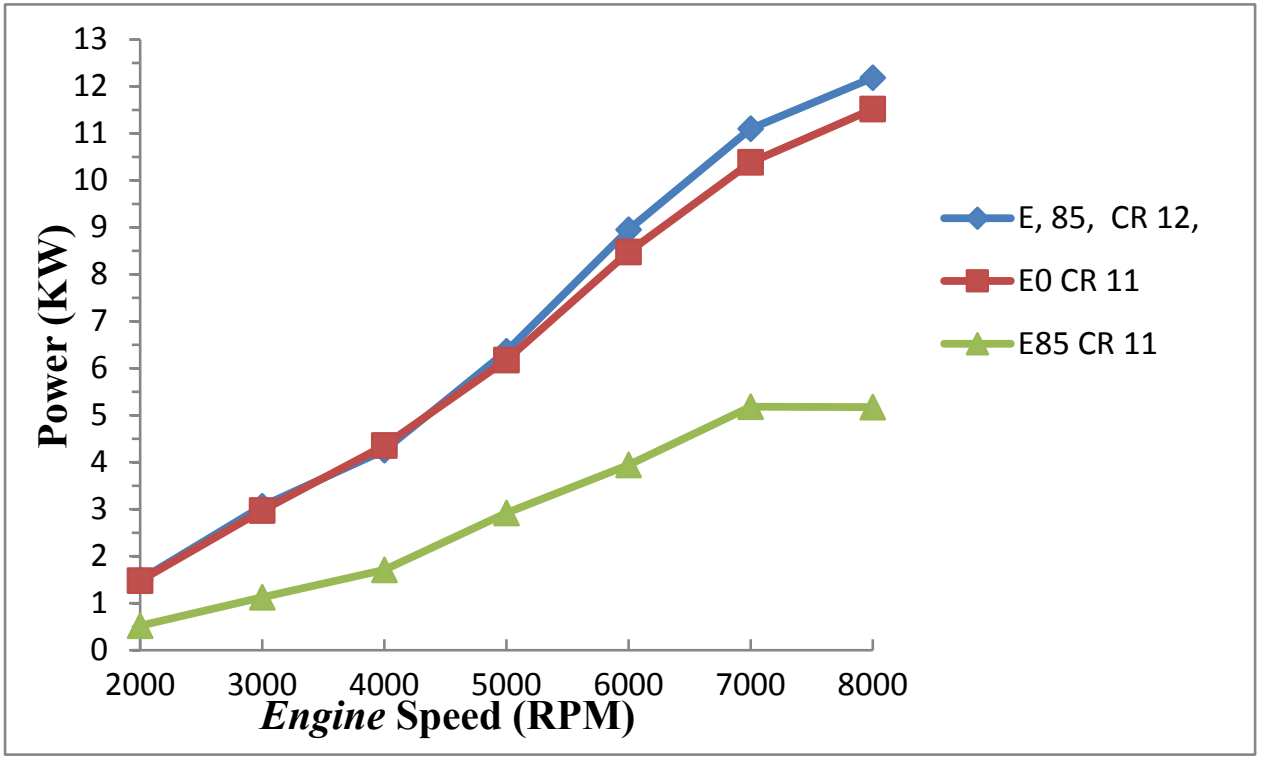

Figure 6. Power Of Experimental

From Figure 6 above shows the trendline of engine power at each engine speed both at the standard compression ratio and at the compression ratio of 12: 1 . The power generated from the engine with standard compression ratios all increases with increasing engine speed from 2000 to $8000 \mathrm{rpm}$. At the standard compression ratio with E0 fuel, the highest power is at $8000 \mathrm{Rpm}$, with a value of $11.5 \mathrm{KW}$, at a compression ratio of 11: 1 with E85 fuel worth 5.1 $\mathrm{KW}$ and at a compression ratio of 12: 1 using E85 fuel, it is worth $12.18 \mathrm{KW}$. The faster the engine rotates, the faster the shaft rotates. However, at a certain rotation the torque and friction that occurs is greater than the increase in rotation that occurs. This will cause the power to decrease. Power will decrease at certain revolutions and generally at high revolutions. In this test, it is found that the power increases with increasing engine speed. This is because testing is only carried out at the $8000 \mathrm{rpm}$ limit.

Figure 5 above if a sample is taken at 8000 engine speed, the engine power fueled by E85 with a compression ratio of 12: 1 increases by 1.5\% when compared to engine power with E0 fuel at a compression ratio of $11: 1$ and increases by $2.3 \%$ when compared to engine power. at a compression ratio of 11: 1 fueled E85. This explains that the power will increase using E85 fuel as the compression ratio increases. 


\section{CONCLUSIONS}

The results showed that by increasing the compression ratio to 12: 1 using E85 torque increased by $4.6 \%$ when compared to the use of e85 at a compression ratio of $11: 1$ and increased by $1.08 \%$ when compared to using E0 at a compression ratio of 11: 1 .

Engine power fueled by E85 with a compression ratio of 12: 1 increases by $1.5 \%$ when compared to engine power with E0 fuel at a compression ratio of $11: 1$ and increases by $2.3 \%$ when compared to engine power. at a compression ratio of 11: 1 fueled E85.

It is necessary to carry out further research on measuring engine temperature and measuring exhaust gas emissions due to the effect that occurs on the engine as a result of increasing the compression ratio.

\section{REFERENCES}

[1] Setiyawan, Atok (2007), "Pengaruh Ignition Timing dan Rasio kompresi Terhadap Unjuk Kerja dan Emisi Gas Buang Motor Bensin Berbahan Bakar Campuran Etanol 85\% dan Premiun 15\%" Seminar Nasional Teknik", 2007, UII Yogyakarta [2] Setiyawan, Atok. 2012. Kajian Eksperimen Pengaruh Etanol pada Gasoline terhadap

Kerja Mesin Bensin. Disertasi Fakultas Teknik : Universitas Indonesia

[3] Jeuland, N., Montagne. X., dan Gaurot. 2014. Potentiality of Ethanol as a Fuel for Dedicated Engine. Journal of Oil \& Gas Science and Technology. Vol. 59, No. 6, pp.560565

[4] J.E Anderson et All "High Octane Number Ethanol-Gasoline blends", Quantifying the Potential Benefits in the United State

[5] Bahattin, Chelik M (2007)" Experimental determination of suitable ethanol-gasoline blend rate at high compression ratio for gasoline engine", Elseveir, Applied Thermal Engineering 31, pp: 278-283

[6] Costa C. Rodrigo, Sodre R. Jose (2010), “Compression ratio effects on an Ethanol/gasoline fuelled engine performance" Elseveir, applied Thermal Enggeneering 31, pp : 278-283

[7] Sudarmanta, B., Junipitoyo, b., Putra,A.B.K., dan Sutantra 2014. Influence of Bioethanol -gasoline blended Fuel on Performance and Emissions Characteristics from Port Injection Sinjai Engine 650 cc. Journal of Applied Mechanics and Materials. Vol. 493, pp. 273-274.

[8] Bahattin, Chelik M (2007)" Experimental determination of suitable ethanol-gasoline blend rate at high compression ratio for gasoline engine", Elseveir, Applied Thermal Engineering 31, pp: 278-283 